\begin{tabular}{lll}
\hline Vol. XL1] & AUGUST 15, 1922 & [No. 15 \\
\hline
\end{tabular}

THE TRAINING OF THE CHEMICAL ENGINEER* R. F. RUTTAN

$\mathrm{T}$

THE grent field for the derelopment of stable chemical industries in Can:u!n is the utilisation of those naturnl resources which we possess in greater quantity, and more conveniently situnted, than other countries. 'This need not call for original research but rather for adaptation to our conditions, of methods, principles and processes nlready known and well tried elsewhere. This is obviously the function of the chemical engineer, and it is from the young chemical engineer that we may expect the kind of industrinl researeh which the country needs at present.

The scientilic army of Great Britain has alway's consisted of a brilliant group of staff officers, but before the war England had not learned how to make the most of her medioere ability. She did not recognise that without the scientific rank and file it would be impossible to staff the industrial research laboratories so as to compete with the more elaborate organisations of Germany and America. The linglish idea was that the two professions should be kept separate, each specially trained for its field of work, and that a chemical job should be done by a chemist and an engineering task by an engineer. 'The two, it was thought, should not be combined because the two subjects were too big for ono man, save in a few exceptional cases. 'This is certainly true when the course of training does not exced three years.

I think that most of the leaders in chemical industry in Englund aro now willing to concede that the engineer should be taught sufficient chemistry to be able to apprecinte the chemist's point of view, and that the chemist should know enough of engineering to realise that he cen safely leave the practical appliention of the processes he devises in the laboratory to the engineer thus trained. 'The principle of " one man, one job," is thoroughly English, but it may be curried too fur. One cumnot overlook the important rôlo played in the chemical industries of Amerien and Germany by $a$ class of scientifie men who aro neitlier highly-trained engineers nor highly-trenined chemists, but who are recognised as a class, and many of whom

- 'llo sulsstanco of an address dellvered at a Jolnt meetling of tho

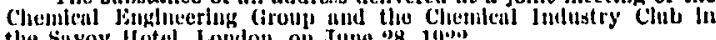
tha sisvoy Ilutel, London, on June 28,1022 . have a great deal more in them than a know ledge of chemistry and of engineering.

It has been pointed out that as the engineer and the chemist beeome more highly trnined and specialised, their paths become more divergent, and their points of view irreconcilable; in short, the experience of many heads of works is that the two types are largely incompatible. A works chemist defined the average engineer as " an empyric who has been trained on cotton waste and engine-oil "; and a works chemist has been described by an engineer as "an organic body more liable than any other of similar nature to spontancous explosions." Chemists and engineers have also been called the physicins and surgeons of industry. On this analogy tho chemical engineer would represent the genernl pructitioner of the chemical industries; like the physician, his chemical knowledge ennbles him to seo below the surfnee, to dingnose from physienl signs unseen changes and conditions, and from his experience to find a remedy for any abnormal renction. Just as there is a limited number of unseen organs in the human body to be studied and observed, so in a chemical works there is a limited number of operations, more or less invisible, going on in chemical units, each with its clinical thermometer, pressure-indicator, etc. attached to give early symptoms of any departure from the normal. The engineer in charge, like the surgeon, has to deal with the adjustment, repair and alterutions of the anatomical units, the works, the aceessible outward portions. Just as minor surgery constitutes a large part of the activities of the general practitioner, so frequent minor adjustments, alterations, improvements and repairs skilfully carried out form the larger part of the duties of the ehemical engineer. bike the gencral practitioner, the chemieal engineer should lunow his limitntions und, when necessary, consult the specialist, the clectrical or hydraulic engineer, or the chemist.

No mulogy, however, should be earried too far, but it is worthy of noto that the best specialists in any field of medieine or surgery wro those who havo spent years as general practitioners. Therefore knowledgo of the general practice of chemistry and engineering in works is a very sound busis on which to build expert lunowledge in either branch of science. 
During the past few years there has been a very prolific discussion regarding the best course of training for the chemical engineer. It has become generally recognised, on both sides of the Atlantic, that progress in industrial chemistry is based upon both engineering and chemistry, and that the Universities have failed to impirt just the right type of education. This is due to the fact that the Universities are unable to teach the control of chemical reactions and the handling of materials on a sulficiently large seale. The hest that can possibly be expected of the University in a course of four years is to gire a broad and scientific foundation. After having onco entered upon the work of his profession it is only in very exceptional cases that a man returns to the University for further trnining in resenrch. Admitting the unsatisfactory and incomplete training which is now being given, the time seems ripe to consider some plan which will provide better-trained chemical engineers. The plan which, in my opinion, gives promise of meeting these requirements, is an adaptation of one which has been developed, and is now being tried, by the MIassachusets Institute of. Wechnology, Boston. 'This unique sclieme of edues. tion, which was erolved by a commitiec of engineers (of which $\mathrm{M}[\mathrm{r}$. A. D. Little was chairman) appointed by the Institute, has up to the present time completely realised the expectr. tions of those who introduced it.

Wo recognise that chemical processes, whether on the laboratory or the factory scale, consist of a series of collected " unit "actions, such as pulverising, mixing, henting, ronsting, absorbing, precipitating, condensing, crystallising, filtering, and clectrolysing. The number of these basic unit operations is not very large, and only a few of them are to be seen in any particular works. 'To afford on insight into the real problems requiring industrial chemical research, the Institute mentioned established five or six chemical engineering and research stations in direct contrat with important industries. Theso were selected with a view to bringing to the attention of the engineering student the largest possible number of tho unit operations of which chemical processes are generally composed. The stations havo a threefold function : (a) practical instruction in chemical entrincering; $(b)$ instruction of ambitious foremen and others in the worles in the fundamontal principles governing their operations; and (c) adrancement of industrial research in special industries. The equipment of each station consists of $\Omega$ smill building of ono storey which contains a small reference library and a very complete collection of photographs and drawings of apparatus and machinery utilised in tho local industry, but not installed in the locality; a conferenco and lecture-room to accommodate fifteen or twenty people; a small laboratory with benches for tho samo number an olfice for the station director ; and a laborntory for specinlised industrinl research, with space and equipment for five graduate rescarch assistants. 'The cost of such an equipment would be from 10 to 20 thousand clollars in different inclustries.

According to the arrangements at the Institute the students leave the University alsout the midlle of their fourth year, and spend the period from January to September in moving from station to station, spending about six weeks at each. An instructor is in charge of each station, and maintains the same strict discipline among the students as is found at the University. Fich day's work is carcfully plamed, and daily lectures on different stages of the process form a part of the system.

The five-year course is designed to fulfil the following objects :-(1) 'lo acquire n first-hand knowledge of the processes, plant and machines in the cquipment. (2) 'lo study the chemical control of industrial processes through the laboratory, and to acquire ability in the interpretation of laboratory data in terms of factory practice. (3) 'lo obtain a general knowledge of modern methods of factory management and control, togcther with methods of apportioning cost of manufacture. (4) To obtain the wider vicwpoint which comes from contact with those who are employed to superintend or carry out factory operations, and to acquire the degree of confidence in handling indust rinl processes and large-sized apparatus which comes from actual participation in the work of the plant. (5) 'To nequire that inspiration for further work in science and research which intimate contact with large progressive inclustries inevitably affords. On returning to the Institute to complete his fifth year, the student follows a course of advanced lectures and laboratory work, the value of which he will appreciate as the result of his experience in the works. The above description is the substanco of the report of the committee presided over by Mr. A. D. Little.

'lhis, in outline, is the object and method of this new plan of educating chemical engineers. It is our purpose to adopt a molified form of it in Canada, and this will require co-operation among the enginecring faculties in Canadian Universities on the one hand, and a successful appenl to the captains of Canadian industry on the other. Tho Universities must agree upon the necessity for a five-yenr courso in chemical enginecring, and be convineed that ono year spent ehicily in works' training is tho best way of employing the students' time. Success or failure will depend very largely upon the manufacturers; without their cordinl co-operation and assistance the plan is obviously doomed to failure. In the United States every industry invited gladly accepted the opportunity of having a station in the works. 'Tho Honorary Advisory Council for Scientilic and Industrial Resenrch has nppointed a committeo to look into this question and to formulato a plan for 
putting it into effect next year. It scems to me a very obvious and effective method of bringing into closer relation the Universities and the industries of Canada, enabling the former to ascertain the important industrial problems of the country, and giving the industries an opportunity of utilising in part the teaching and resenrch powers of the Universities. Not only would this seheme give our students in ehemical engincering a range of experience impossible to obtain otherwise, but the stations could offer special courses in the technology of their industry to superintendents, foremen, etc., thus forming $\Omega$ sort of mirersity extension in chemical industry. The plan lends itself with peculiar effectiveness to the derelopment of industrial resenrch at each station. 'The director in charge of the station would obviously be a well-trained chemist or chemical engineer who has specialised, or intends to specialise, along the lines of the particular industry or industries with which he is connected.

The application of this scheme of training to C'anadian conditions will not be easy. In the first plnce, the total number of graduntes in ehemical engineering and chemistry in Canada is less than is annually turned out by the Institute of Technology; hence the field from which we ean select is smaller. The average student at the Institute is financially better able to spend the extra year, with its additional tuition fees and travelling expenses, than is our Canadian student. Again, few industries aro on a scale comparable with many in the United States. But these diliculties are not insuperable. There is little doubt that industrial chemistry is offering such a future to our technically-trained graduates that chemical engincering is rupidly becoming the most attractive carcer for the engineering student, and tho required number will soon be available. If the universities gave the Bachelor degree at the end of four years und a Master's degrec in Scienco after five years; if the fees were made as low as possible and substantial Covernment assistance be given to these training centres, the obvious value of this practical training would soon create a competition among the students for the privilege of being admitted to the course.

'The station in each centre would become the scientific burenu of information and resenrch for the local industries, and would go far to introduce an atmosphere of science into those industries in which chemistry plays a purt.

Finally, I feel strongly that the chemical engineer so trained is just the type of man to develop our industries. Ho would be a University man familinr with the engineering problems presented by chenical industries, one whose cupacity for initintivo and for attacking soientifically an industrinl problem would bo many times that of the present science grnduate, howover good his university training may havo been.

\section{CONSTRUCTIVE INDUSTRIAL HYGIENE IN THE INDIARUBBER INDUSTRY}

\author{
C. A. KLEIN
}

$\mathrm{E}$ ARLY in 1921 the Homo Sccretary, under Section 79 of the Fintory Act of 1901, certilied as dangerous the following processes incidental to the manufacture of indiarubber and indiarubber goods :-

(a) Vulcanising by means of the cold cure process or by any other process involving the use of carbon bisulphide, sulphur chloride, carbon-chlorine compounds or benzol (puro or commercial);

(b) Any process involving tho use of lead or compounds of lead.

This certification by the Homo Secretary is a necessary preliminary under the Act when it is intended to institute regulntions for the hygienic control of an industrial process.

Shortly after the certification of tho abovo processes as dangerous, tho Secretary of State issued draft regulations which it was proposed to institute in connexion with these processes and, as prescribed, the draft regulations were submitted to those coneerned and interested in tho matter. After mutual criticism and discussion, a final form was agreed and Statutory Rules and Orders, dated Maroh 31. 1922, now known as tho "Indiarubber Regulations, 1022," camo into operation on May 1 of this year.

Tho regulations divide tho above-named processes into two kinds, viz., "fume processes" -i.e., those referred to under $(a)$ as aboveand "lead processes," or those described under heading (b). Tho regulations for the two types of processes aro almost entirely distinct, but few having dual reference.

In the regulations dealing with "fume processes," the essential fenture is protection against the injurious effects of the vapours of volatilo solvents used in indiarubber manufacture, the provisions being for minimum ago of omployment, limitation of hours worked, prohibition of the use of such processes in the open air, the application of oxhaust ciraught or (when only benzene-puro or commerciul bonzol-is used) of officient ventilation, the adoption of means to minimise the amount of vapour entering tho air, messroom, medical oxamination at prescribed intervals, maintenanco of health register, and rules for tho recmployment of persons suspended by tho cortifying factory surgeon.

These now regulations supersedo the Special Rules in operation sinco Mny 1, 1898, for "The vulcanising of indiarubber by menns of bisulphide of carbon," and aro moro comprehensive and applicablo to processes in which other volatilo products aro used.

'The inclusion of liquids contuining benzeno and tho carbon-chlorine compounds, inclicates 